\title{
Singapore International Film Festival 2002
}

\author{
By Brandon Wee
}

\section{Fall 2002 Issue of KINEMA}

The SIFF celebrated its fifteenth birthday in typical festival frenzy. Seguing into another year, the event drew intense emotions from persistent mechanical glitches and over-air-conditioned halls but also from the pleasure of having been gratified by grand moving images. Some 390 films from 40 countries shaped the spread, with spotlights on contemporary fixations: The theme of "globalisation" had an exclusive programme dedicated to filmmakers' representations of this loaded buzzword. Another catch phrase, Digital Cinema, was given further resonance with the introductory Asian Digital Film Awards plus a medley of international features 'digitised' by the proselytising logic of economy and portability. Another favourite was animation, with the invisible world of Asian animations taking centre stage, and also tributes to manga guru Tezuka Osamu and Jan $\AA$ vankmajer, a man who begrudges the animator label.

Kandahar (2001), Mohsen Makhmalbaf's prescient essay on humanity opened the festival to little surprise. Although an unusually conservative narrative -- a race-against-time tale subtended with road movie sensibilities, for Makhmalbaf, this is less his latest art house spectacle than a personal resolve to remedy the distressing state of civil affairs in Afghanistan. Wrapping up the 17-day event was Tsai Ming-liang's What Time Is It There? (2001), another of his exploratory canvases on isolation and the urban experience, this round across time and space. Tsai's citation of FranÃßois Truffaut's The 400 Blows (1959) tosses about interesting symbolisms but even Jean-Pierre LÃ@aud's cameo does little to enthuse an otherwise detached viewing.

From Singapore, critic-turned-filmmaker Sandi Tan's short, Gourmet Baby (2001) was a neat metaphor on desire but problematic for its representation of social class determinants such as Singapore's cultural fetish for food. Adi Yadoni's Reflections of the Misunderstood Mat Rockers (2002) is a documentary that attempts to empower the local community of Malay rock music lovers besieged by pejorative stereotypes, yet it overlooks the politics of marginality where the external imperatives of history, ethnicity and gender peculiar to Singapore are concerned. Joyceln Woo and Colin Goh's TalkingCock The Movie (2001) [to "talk cock" is a Singapore colloquial construct meaning to chitchat idly] comprises four slice-of-life stories about the quirks of Singapore life and has been described as a "surrealist comedy" by the filmmakers. However, one wishes its sense of humour and irreverence were less self-conscious and reactionary, a symptom plaguing most Singapore films in search of an "identity".

The SIFF has always been a bastion of faith in Asian, particularly Southeast Asian cinema. But as festival director Philip Cheah recalls, it was difficult initially to find an audience due to prejudices caused by Hollywood's hegemonic gloss. Happily, audiences are now hungry for the latest features from China, Hong Kong, Japan and especially Korea. But although it's been about a decade since the festival made a conscious effort to initiate Singapore audiences to the cinemas of the Southeast Asian region -- ironic, considering Singapore's proximity to her neighbours and their historical and cultural ties within this small geographical sphere -- one feels, despite the inductions, that they do not attract half as much appraisal as their North Asian counterparts. This year's line-up has been absolutely enduring. The 5-hour Batang West Side (2001) by Lav Diaz is a poignant work that examines the Filipino Diaspora in America -- a revelation in interrogative scope. Another veritable standout was Mike de Leon's Third World Hero, a fresh and amusing perspective that critiques the historical representation and hero worship of the Philippines' national icon, JosÃ® Rizal.

Previously retrospected Southeast Asian directors include Ishmael Bernal, Arifin C. Noer, Mario O'Hara, P. Ramlee and Cherd Songsri. This year, the SIFF saluted Thailand's Ratana Pestonji (1908-1970), who directed only four features in his career and whose cinematographic prowess clearly eclipsed his directorial interests. Black Silk (1961), which he wrote, produced, directed, photographed, edited and in which he cast his daughter, is possibly his finest, even though his directorial debut Country Hotel (1957) is revered among critics and elders. Set in a one-room inn, Murphy's Law becomes an indispensable narrative agent when the sole guest is driven crazy by the absurdities of its other inhabitants.

Other remarkable mentions this year include The Coen Brothers' The Man Who Wasn't There (2001), with 
a dispassionate Billy Bob Thornton as the urban Marlboro Man, Imamura Shohei's intriguing Warm Water Under A Red Bridge (2001), Milcho Manchevski's Dust (2001), Lindsey Merrison's Friends In High Places (2001), Park Kiyong's Camel(s) (2001), Riri Riza's Eliana, Eliana (2002), Julian Samuel's The Library In Crisis (2002), and Å vankmajer's delectably perverse Conspirators of Pleasure (1996).

If figures are any indication, the SIFF is developing assuredly amid growing public support. In 1987, it started out with 70 titles. Last year saw fives times that number. This year, and against the odds of waning sponsorship, that number has bettered slightly. Come next spring, film buffs will be thirsting for SIFF's sixteenth line-up. With any luck, it will be the sweetest one yet.

SILVER SCREEN AWARDS

Asian Feature Films

Best Film: Batang West Side (The Philippines, Lav Diaz, 2001)

SFC Young Cinema Award: Eliana, Eliana (Indonesia, Riri Riza, 2002)

Special Jury Prize: Seafood (China/Hong Kong, Zhu Wen, 2001)

Best Director: Away From Home (Turkey, Semih Kaplanoglu, 2001)

Best Actor: Jia Hongsheng in Quitting (China, Zhang Yang, 2001)

Best Actress: Dian Sastrowardoyo in Whispering Sands (Indonesia, Nan Achnas, 2001)

Singapore Short Films

Best Film: The Call Home (Singapore, Han Yew Kwang, 2001)

Special Jury Prize: Eve of Adha (Singapore, Leonard Yip, 2001)

Best Director: The Secret Heaven (Singapore, Sun Koh Boon Luang, 2002)

Special Achievement Award: 15 (Singapore, Royston Tan, 2002)

Critics Jury

NETPAC/FIPRESCI Award: Eliana, Eliana (Indonesia, Riri Riza, 2002)

Special Mention: I-San Special (Thailand, Mingmongkol Sonakul, 2002)

Asian Digital Film Awards

Critics Prize: Lost (Malaysia, Amir Muhammad, 2002)

Audience Prize: In Search of Afghanistan (Singapore, Melvinder Kanth, Ismail bin Ishak, 2001)

\section{Author Information}

Brandon WEE lives in Toronto. He has written for Asia Pacific Arts (Los Angeles), Cineaste (New York), Cinema Scope (Toronto), Ricepaper (Vancouver), and Senses of Cinema (Melbourne). 